\title{
Use of maize silage to improve pasture persistence in dairy farm systems: a review
}

\author{
R.J. DENSLEY, I.D. WILLIAMS, J.J KLEINMANS, S.B. MCCARTER, R. TSIMBA \\ Genetic Technologies Ltd., P.O. Box 105 303, Auckland \\ rdensley@genetic.co.nz
}

\begin{abstract}
Maize is a drought tolerant crop that produces high dry matter yields. Growing maize silage as part of a pasture renewal programme can help improve pasture persistence by reducing the level of weeds, insect pests and carryover ryegrass seed. Feeding maize silage to dairy cows results in pasture substitution. This decreases grazing pressure and can be used to manipulate farm pasture cover levels reducing overgrazing. The combination of maize silage and a well-designed stand-off pad with feeding bins allows farmers to keep cows off wet pastures reducing pugging damage and subsequent losses in pasture production without compromising milk production or animal welfare. Maize hybrid selection is critical to ensure timely regrassing. Crop simulation models such as CERES-maize may be useful to determine the best maize hybrid maturity $\mathrm{x}$ planting date combinations required to maximise silage yield and meet desired silage harvest and regrassing dates. Best-practice maize silage management including seed bed preparation, weed control and insecticide-treated maize seed will help farmers achieve high yields of silage and assist in the subsequent establishment of high yielding and persistent pastures.
\end{abstract}

Keywords: pasture persistence, maize silage, feed pad

\section{Introduction}

Ryegrass-clover pastures have been the basis of New Zealand's competitive advantage in livestock production. However, poor pasture persistence is currently a major concern with open pastures, weed invasion and decreased dry matter yields being seen on individual farms and being reported in the media. Factors affecting persistency of pasture include grazing management, climatic stresses, weed competition, pests and diseases. Many of these factors interact and therefore it is difficult to determine the primary cause of lost productivity. This review examines how growing maize silage as part of a pasture renewal programme and feeding it on a stand-off pad can help improve pasture persistence.

\section{Pasture persistence}

During the last 30 years, dairy farmers have significantly intensified production; per cow values have increased from $144 \mathrm{~kg}$ milkfat in 1981/82 to $184 \mathrm{~kg}$ milkfat in 2008/09 (LIC 2009). Over the same period, stocking rate has increased over $1.1 \%$ per annum from 2.10 to 2.83 cows/ha (LIC 2009). A greater number of cows per hectare producing more milk per cow has lifted feed demand faster than the rate of genetic gain in perennial ryegrass which is estimated to be $0.4 \%$ annually (Easton et al. 2002). While a combination of nitrogen boosted pasture, home-grown and brought-in supplements have partially offset the increased feed demand, grazing pressure has intensified on many farms.

Warmer, drier summers in major dairy districts have caused a reduction in pasture growth rates with increased pressure on pasture cover levels. There has been a mean temperature increase of about $0.9^{\circ} \mathrm{C}$ over the last 100 years (Wratt 2009). An analysis of data since 1930 shows an increase in mean and extreme rainfall in the west, with some decreases in mean and extreme rainfall (plus increasing dry spell duration) generally seen in the north and east of both islands (Wratt 2009). For each of the last 3 years, summer (December to February) rainfall has been below the 30year average in a number of areas including Whangarei (NIWA climate station AWS 54737), Whakatane (B76995), Hamilton (C75834) and Stratford (E94334) (NIWA pers. comm.)

Livestock treading (especially in winter and early spring) can cause short-term decreases in pasture production of up to $80 \%$ (Ledgard et al. 1996). Moderate and severe pugging of poor draining soil resulted in annual pasture production decreases of $21 \%$ and $45 \%$ respectively. Clover showed a much greater decrease in production than grass $(65 \%$ vs. $38 \%)$. For a Waikato farm, moderate pugging of $50 \%$ of the farm and severe pugging of $10 \%$ of the farm was predicted to decrease whole farm milk production by $16 \%$ (Menneer et al. 2001). A 3 -year study showed that paddocks with no pugging produced $28 \%$ greater pasture yields in the July - September period than conventional year-round dairy grazing systems (Drewry 2003).

\section{Benefits of growing and feeding maize silage}

Maize (a $\mathrm{C} 4$ species) is much more drought tolerant than $\mathrm{C} 3$ pasture grasses. It has an effective rooting 
depth of 150-180 cm (Kovacs et al. 1995; Grignani et al. 2007) which allows it to access soil water from depths two to three times greater than most $\mathrm{C} 3$ pasture grasses. Maize also has up to twice the water use efficiency of perennial ryegrass on an annual basis and up to three times on a summer seasonal basis (Neal et al. 2005; 2007).

Significant global research programmes have targeted additional maize yield, improved agronomic stability and quality traits. Since 1930 , maize silage whole plant dry matter yield has increased at the rate of 128 to $164 \mathrm{~kg} \mathrm{DM} / \mathrm{ha} /$ year. Whole plant, stover and cob yields have increased $1.4,0.7$ and $2.4 \%$ per year respectively (Lauer et al. 2001). These genetic gains have allowed growers to achieve higher dry matter yields in a given number of days from planting to harvest, or the same amount of dry matter in fewer days from planting to harvest. Local dry matter yields of $27.8 \mathrm{t} / \mathrm{ha}$ (Te Awamutu; Densley et al. 2006); $33.0 \mathrm{t} /$ ha (Hamilton; Minneé et al. 2009); 23.2 (Lincoln; de Ruiter et al. 2009) and 30.5 - 31.1 t/ha (Hawera; de Ruiter 2010) have been reported.

Maize silage can be grown on most New Zealand farms for 14-24 c/kg DM (Pioneer Seeds 2010). Crops grown in effluent paddocks produce high yields without the need for additional fertiliser (Johnstone et al. 2010) reducing feed cost by $4-6 \mathrm{c} / \mathrm{kg} / \mathrm{DM}$.

Maize is an ideal break crop in a pasture renewal process. Typically, pastures are sprayed out using glyphosate in the spring (October-November) and cultivated prior to maize establishment. The cultivation process allows farmers to apply fertiliser, incorporate lime and address drainage issues that may have been negatively impacting pasture persistence.

The majority of maize silage seed that is planted in New Zealand is insecticide treated. Modern low-toxic insecticides such as Poncho $^{\circledR}$ (a.i. clothianidin) form a protective layer around the seed and are taken up by the roots, thus protecting the plant systemically (Altmann 2003). Poncho ${ }^{\circledR}$ is registered to control Argentine stem weevil (Listronotus bonariensis), black beetle (Heteronychus arator) and greasy cutworm (Agrotis ipsilon).

Cropping removes the normal feed source for pasture pests such as black beetle, Argentine stem weevil, pasture nematodes and grass grub. This interrupts their breeding cycle and reduces insect pressure on seedling plants during the pasture renewal process (Watson \& Mercer 2000; Eerens et al. 2005)

Gerard et al. (2009) investigated clover establishment in new pasture following maize, turnips or grass in Northland and Waikato. There were substantial carryover populations of grass grub larvae $\left(21 / \mathrm{m}^{2}\right)$, white-fringed weevil larvae $\left(17 / \mathrm{m}^{2}\right)$ and black beetle adults $\left(3 / \mathrm{m}^{2}\right)$ in a Waikato ex-grass paddock while paddocks coming out of non-host crops (maize and turnips) had none of these pests. Production data from the Northland site showed that in the December following April pasture renewal, the ex-maize and exturnip paddocks had $54 \%$ and $79 \%$ respectively more pasture than the ex-grass paddocks. The benefit of successful pasture establishment appeared to last with Year 3 ex-crop pastures in the Waikato having more clover, fewer weeds and higher autumn production compared with ex-grass pastures.

Maize silage is typically harvested in the late summer to early autumn (February - April) and paddocks that have hard-to-kill perennial weeds such as couch (Agropyron repens), Californian thistle (Cirsium arvense), kikuyu (Pennisetum clandestinum), Mercer grass (Paspalum distichum) or Indian doab (Cynodon dactylon) can be sprayed again if necessary prior to the establishment of new pasture.

The genetic yield potential of perennial ryegrass is increasing. An analysis of research data showed that ryegrass cultivars available in 1991-96 produced on average $6 \%$ more herbage annually and $9 \%$ in summer than cultivars available prior to 1991 (Easton et al. 2001). Cropping prior to pasture renewal can reduce the carryover of older, lower yielding ryegrasses. A Waikato trial (Bluett et al. 2001) showed pre-sowing management generated large differences in viable ryegrass seed density ranging from 25 to $2,555 \mathrm{seeds} / \mathrm{m}^{2}$ for turnip and hay crop treatments respectively. Spray/ cultivation and double-spray/fallow establishment methods were effective in reducing contamination with volunteer ryegrass plants ( 8 and 34 plants $/ \mathrm{m}^{2}$ respectively); in contrast to double drilling ryegrass seed into hard-grazed existing pasture (581 plants $\left./ \mathrm{m}^{2}\right)$.

While most forage crops must be fed when mature, a key benefit of maize silage is that it can be stored on-farm and used to fill genuine feed deficits providing its quality is maintained through effective compaction and sealing. Supplementary feeding results in pasture substitution (Roche and Holmes 2007). This reduces grazing pressure lifting post-grazing residuals. Forages including maize silage have higher substitution rates than concentrates (Holmes et al. 2003) and can be used to manipulate farm pasture cover levels reducing overgrazing. More severe grazing $(<3 \mathrm{~cm})$ reduces pasture regrowth and can reduce pasture persistence due to removal of plant energy reserves (Lee et al. 2008). Thus maize silage can be fed strategically to ensure pastures are not overgrazed.

The combination of maize silage and a well-designed stand-off pad with feeding facilities allows farmers to keep cows off wet pastures without compromising production or animal welfare. 


\section{Best-practice maize management to optimise pasture persistence}

Maize has a high environmental production potential (Brown et al. 2007). Good crop management methods will ensure growers maximise maize yields and establish high yielding pasture after maize silage harvest.

\section{Hybrid choice}

The choice of hybrid is critical to maximise maize yield and ensure timely regrassing. Maize development responds to heat unit accumulation. Therefore time to maturity and duration from planting to harvest vary for different hybrids and can change for different seasons, growing environments and different planting dates within the same growing environment. Crop simulation models such as CERES-Maize can be used to determine the best maize hybrid maturity $\mathrm{x}$ planting date combinations required to maximise silage yield and meet the desired harvest date (Tsimba 2011).

\section{Crop management}

Pasture should be sprayed out using glyphosate. Lime and/or fertiliser should be applied according to soil test results. The cropping area should be cultivated to produce a fine, even and weed-free seed bed. Growers should plant insecticide-treated maize seed and apply pre-emergence grass weed herbicides immediately post-planting. Crops should be monitored for broadleaf weeds on a regular basis and the appropriate herbicides should be applied where necessary.

\section{Sow new pasture}

If grass or broadleaf weeds are present after maize silage harvest, the paddock should be sprayed with glyphosate prior to the establishment of permanent pasture. Pasture seed can be direct drilled into the maize stubble to speed up the regrassing process. Where pasture establishment is delayed due to unfavourable autumn planting conditions, late crop harvest or delays in pasture seed procurement, farmers should consider planting Italian ryegrass rather than permanent pasture mixtures that contain slow emerging species such as cocksfoot, timothy, tall fescue or species like white clover which has low seedling growth (Moot et al. 2000).

\section{Maize silage}

Growing maize silage on-farm will reduce the grazing area. In the first year it may be necessary to apply additional nitrogen or use bought-in supplements to prevent overgrazing. In the second and subsequent years, maize silage from the previous crop can be carried over and fed in the summer and autumn while the next maize crop is in the ground. Maize silage response rates in cows are in the range $32-82$ and $66-179 \mathrm{~g} \mathrm{MS} / \mathrm{kg} \mathrm{DM}$ for the summer and autumn respectively (Deane 1999).

\section{Summary}

Growing maize silage as part of a pasture renewal programme can help improve pasture persistence by reducing the level of weeds, insect pests and carryover ryegrass seed. Feeding maize silage results in pasture substitution. This effect can be used to reduce overgrazing of pasture. The combination of maize silage and a well-designed stand-off pad with feeding facilities allows farmers to keep cows off wet pastures thereby decreasing pugging damage and subsequent losses in pasture production without compromising milk production or animal welfare. Best-practice maize silage management will assist in the successful establishment of high yielding and persistent pastures.

\section{REFERENCES}

Altmann, R. 2003. Poncho ${ }^{\circledR}$ a new insecticidal seed treatment for the control of major maize pests in Europe. Pflanzenschutz - Nachrichten Bayer 56/2003: 1. http://n.ethz.ch/ dhegglin/private/ Clothianidin/Poncho_Bayer.pdf.

Bluett, S.J.; Burggraaf, V.T.; Hume, D.E.; Tapper, B.A.; Thom, E.R. 2001. Establishment of ryegrass pastures containing a novel endophyte. Proceedings of the New Zealand Grassland Association 63: 259-265.

Brown, H.E.; Li, F.Y.; Wilson, D.R.; Fletcher, A. 2007. Geographical and seasonal variation in potential forage production in New Zealand. pp. 343-349. In: Proceedings Australasian Dairy Science Symposium.

Deane, T. 1999. The profitable use of supplementary feeds in pasture based dairy farm systems. Proceedings of the Ruakura Farmers' Conference 51: 64-77.

Densley, R.J.; Austin, G.M.; Williams, I.D.; Tsimba, R.; Edmeades, G.O. 2006. Maize silage and winter crop options to maximize dry matter and energy for NZ dairy systems. Proceedings of the New Zealand Grassland Association 64: 173-179.

de Ruiter, J.M.; Waimate West Demonstration Farm: Progress Report Year 3 (2009-2010) August 2010.

de Ruiter, J.M.; Fletcher, A.; Maley, S.; Sim, R.; George, M. 2009. Aiming for $45 \mathrm{t} / \mathrm{ha}$ per annum: yield of supplementary feed crops grown in sequences designed for maximum productivity. Proceedings of the New Zealand Grassland Association 71: 107-116.

Drewry, J.J. 2003. Dairy grazing strategies to minimise soil pugging and compaction in the Waikato. Proceedings of the New Zealand Grassland Association 65: 99-103.

Easton, H.S.; Baird, D.B.; Cameron, N.E.; Kerr, 
G.A.; Norriss, M.; Stewart, A.V. 2001. Perennial ryegrass cultivars: herbage yield in multi-site plot trials. Proceedings of the New Zealand Grassland Association 63: 183-188.

Easton, S.; Amyes J.M.; Cameron, N.E.; Green, R.B.; Kerr, G.A.; Norriss, M.G.; Stewart, A.V. 2002. Pasture plant breeding in New Zealand: where to from here? Proceedings of the New Zealand Grassland Association 68: 193-197.

Eerens, J.P.J; Hardwick, S.; Gerard, P.J.; Willoughby, B.E. 2005. Clover root weevil (Sitona lepidus) in New Zealand: the story so far. Proceedings of the New Zealand Grassland Association 67: 19-22.

Gerard, P.J.; Cooper, B.M.; Eden, T.M.; Howlett, S.A.; Lane, P.M.S.; Panckhurst, K.A.; Willoughby, B.E.; Wilson, D.J. 2009. Impact of ryegrass selection and paddock history on clover establishment in new dairy pasture. Proceedings of the New Zealand Grassland Association 71: 133-137.

Grignani, C.; Zavattoro, L.; Sacco, D.; Monaco, S. 2007. Production, nitrogen and carbon balance of maize-based forage systems. European Journal of Agronomy 26: 442-453.

Holmes, C.W; Brookes, I.M.; Garrick, D.J.; MacKenzie, D.D.S.; Parkinson, T.J.; Wilson, G.F. 2003. Milk production from pasture. Massey University, New Zealand. $602 \mathrm{pp}$.

Johnstone, P.R.; Arnold, N.P.; Wallace, D.F. 2010. Managing dairy shed effluent using maize - Year 3. A report prepared for Foundation for Arable Research Project No M07/03. Plant \& Food Research, Auckland, New Zealand. 27 pp.

Kovacs, G.J.; Nemeth, T.; Ritchie, J.T. 1995: Testing simulation models for the assessment of crop production and nitrate leaching in Hungary. Accessed 25/11/2010 (http://www.taki,iif.hu/cikkek/agrisys. doc). $13 \mathrm{pp}$.

Lauer, J.G.; Coors, J.G.; Flannery, P.J. 2001. Forage yield and quality of corn cultivars developed in different eras. Crop Science 41: 1449-1455.

Ledgard, S.F.; Thom, E.R.; Singleton, P.L.; Thorrold, B.S.; Edmeades, D.C. 1996. Environmental impacts of dairy systems. Proceedings of the Ruakura Farmers' Conference 48: 23-33.

Lee, J.M.; Donaghy, D.J.; Roche, J.R. 2008. Effect of defoliation severity on regrowth and nutritive value of perennial ryegrass (Lolium perenne $\mathrm{L}$ ) dominant swards. Agronomy Journal 100: 308-314.

Livestock Improvement Corporation, 2009. New Zealand Dairy Statistics. Accessed 25/11/2010 www.dairynz.co.nz/dairystatistics. 48 pp.

Menneer, J.; Ledgard, S.; McLay, C.; Silvester, W. 2001. What impact does dairy cow pugging have on clover $\mathrm{N}_{2}$ fixation and long-term farm production?
Proceedings of the New Zealand Grassland Association 63: 63-67.

Minneé, E.M.K.; Fletcher, A.L.; De Ruiter, J.M.; Clark, D.A. 2009. Forage crop sequences for pastoral systems in northern New Zealand. Proceedings of the New Zealand Grassland Association 71: 93-100.

Moot, D.J.; Scott, M.R.; Roy, A.M.; Nicholls, A.C. 2000. Base temperature and thermal time requirements for germination and emergence of pasture species. New Zealand Journal of Agricultural Research 43: 15-25.

Neal, J.; Fulkerson, W.; Greenwood, K. 2005: How crops and pastures respond to water stress. Interdrought II, Bolgna, Italy, 24-28 September, 2005. Accessed 25/11/2010 (http://www.plantstress.com/id2/).

Neal, J.S.; Greenwood, K.L.; de Ruiter, J.M.; Martin, R.J. 2007: Water use efficiency, productivity and profitability - how do forages compare? 'Meeting the Challenges for pasture-based dairying'. pp. 240255. In: Proceedings of Australasian Dairy Science Symposium.

Pioneer ${ }^{\circledR}$ brand Seeds, 2010. Pioneer Maize Silage 2010/2011. 37 pp.

Roche, J.R.; Holmes, C.W. 2007. Milk Production, Body Condition Score and reproduction responses to supplementation in grazing dairy cows. pp 253267. In: South Island Dairy Event, 18-20 June 2007, Lincoln University, New Zealand.

Tsimba, R. 2011. Development of a decision support system to determine the best maize (Zea mays. L) hybrid - planting date option under typical New Zealand management systems. PhD thesis, Massey University, New Zealand.

Watson, R.N.; Mercer, C.F. 2000. Pasture nematodes: the major scourge of white clover. Proceedings of the New Zealand Grassland Association 62: 195-199.

Wratt, D.S. 2009. Climate change, climate variability and the future. Proceedings of the New Zealand Grassland Association 71: 57-59. 
